\title{
Dynamics of pyrethroid resistance in malaria vectors in southern Benin following a large scale implementation of vector control interventions
}

Gildas A. Yahouédo ${ }^{1,2^{*}}$, Sylvie Cornelie ${ }^{1,2}$, Innocent Djègbè ${ }^{1,2}$, Justine Ahlonsou ${ }^{2}$, Sidick Aboubakar ${ }^{2}$, Christophe Soares $^{2}$, Martin Akogbéto ${ }^{2}$ and Vincent Corbel ${ }^{1,3}$

\begin{abstract}
Background: Large-scale implementation of Indoor Residual Spraying and Insecticide Treated Nets has been implemented in Plateau Department, Benin between 2011 and 2014. The purpose of this study was to monitor the frequency and mechanisms of pyrethroid resistance in malaria vectors following the implementation of vector control tools for malaria prevention.

Methods: Anopheles larvae were collected in 13 villages twice a year from 2012 to 2014 . WHO tube tests were used to assess the phenotypic resistance of each population to $0.05 \%$ deltamethrin. Sibling species within Anopheles gambiae complex were identified by PCR techniques. Taqman and biochemical assays were performed to identify the presence of $k d r$ mutations in individual mosquitoes and to detect any increase in the activity of enzymes putatively involved in insecticide metabolism (oxidases, esterase and glutathione-S-transferases). Quantitative real time PCR was used to measure the expression of three metabolic genes involved in pyrethroid resistance (CYP6P3, CYP6M2 and GSTD3).

Results: Anopheles populations showed $<90 \%$ mortality to deltamethrin in all villages and at all time points. The $1014 \mathrm{~F} \mathrm{kdr}$ allele frequency was close to fixation (> 0.9) over the sampling periods in both An. gambiae and An. coluzzii. Biochemical assays showed higher activities of alpha esterase and GST in field malaria vector populations compared to susceptible mosquitoes. qPCR assays showed a significant increase of CYP6P3, CYP6M2 GSTD3 expression in An. gambiae after a three-year implementation of LLINs.

Conclusion: The study confirmed that deltamethrin resistance is widespread in malaria vectors in Southern Benin. We suspect that the increase in deltamethrin resistance between 2012 and 2014 resulted from an increased expression of metabolic detoxification genes (CYP6M2 and CYP6P3) rather than from kdr mutations. It is urgent to evaluate further the impact of metabolic resistance on the efficacy of vector control interventions using pyrethroid insecticides.
\end{abstract}

Keywords: Malaria, Vector control, Anopheles, Insecticide resistance, kdr, Metabolic gene

\footnotetext{
* Correspondence: gildas.yahouedo@ird.fr

'Institut de Recherche pour le Développement (IRD), Maladies Infectieuses et

Vecteurs: Ecologie, Génétique, Evolution et Contrôle (MIVEGEC), UMR

UM1-UM2 - CNRS 5290 - IRD 224, Montpellier, France

${ }^{2}$ Centre de Recherche Entomologique de Cotonou (CREC), Cotonou, Bénin

Full list of author information is available at the end of the article
} 


\section{Background}

Global malaria vector control efforts rely on the use of Long Lasting Insecticide Nets (LLINs) and Indoor Residual Spraying (IRS). Twelve insecticides belonging to four chemical classes (organochlorines, organophosphates, carbamates and pyrethroids) are approved by the World Health Organization (WHO) for malaria vector control. All of these insecticides are neurotoxic and either target acetyl cholinesterase in the synapses or the voltage-gated sodium channel (VGSC). Pyrethroids are the only insecticides recommended by the WHO for LLINs because of their low mammalian toxicity, fast action, and high insecticidal activity [1]. Unfortunately, pyrethroid resistance has developed in most malaria vector species worldwide including Africa [2]. Indeed, two major mechanisms are known to confer pyrethroid resistance in malaria vectors: target site modification ( $k d r$ mutations) and increased metabolism of insecticides through detoxifying enzymes. The L1014F and L1014S substitutions in the para VGSC in the domains III-IV are known to decrease affinity of pyrethroids for this receptor [3]. Recently the mutation N1575Y has been described to potentiate the effect of the $L 1014 F$ mutation [4]. The second resistance mechanism is called "metabolic" through higher catalytic properties and/or overexpression of carboxylesterases (COEs), cytochrome P450 mono-oxygenases (P450s) and Glutathione S-Transferases (GSTs) [5]. Some members of these families such as CYP6M2, CYP6Z2, CYP6P3 are known to contribute to pyrethroid detoxification in Anopheles mosquitoes [6]. Both metabolic and target site $(k d r)$ resistance are present west Africa [7] and particularly Benin [8] and are suspected to reduce the efficacy of vector control intervention $[9,10]$.

Since 2007 the National Malaria Control Program (NMCP) in Benin has implemented a nationwide distribution of LLINs. In 2011, 5,135,942 LLINs were distributed in Benin [11] followed by 5,663,220 in 2014 with a coverage of $97 \%$ and $80 \%$ respectively. In the study area, LLINs distributed in 2011 contained permethrin/ deltamethrin (pyrethroids) while those distributed in 2014 contained deltamethrin only (data from NMCP). After implementation of vector control interventions, it is essential to monitor any changes in susceptibility/resistance status of malaria vectors populations to public health insecticide (WHO 2015). Many cross-sectional studies were done to address the spatial distribution of pyrethroid resistance in Anopheles at a given time [12] but few longitudinal studies were conducted to address temporal changes in pyrethroid resistance phenotype following the implementation of vector control interventions.

The aim of this study was to investigate the dynamic of pyrethroid resistance in malaria vectors from 2012 to 2014 in 13 villages of Plateau Department and to characterize the mechanisms involved by monitoring changes in the frequency and expression of pyrethroidresistance markers. The outcomes shall help the NMCP to implement more effective vector control strategy against pyrethroid resistance populations.

\section{Methods}

Study area

The thirteen villages, selected on the basis of entomological and epidemiological criteria, were located in southeast Benin. They belonged to four districts: Ifangni, Sakete, Pobe, Ketou and were visited for mosquito collection (Table 1). The study area is characterised by two rainy seasons from April to July and from September to October. The area is 3264 square $\mathrm{km}$ with a total population of 407,116 inhabitants (General Census of Population and Housing, 2002). Inhabitants of these villages are mostly farmers, traders, gardeners and fish breeders. Farmers grow cereals (maize, groundnuts, and beans), tubers (yams, manioc) and some vegetable crops such as tomato (Ifangni), chilli (Ketou). The fish breeding was only conducted in Itassoumba village (Ifangni) where tilapias and catfish were bred in large fishponds. These ponds provide a permanent breeding habitat for mosquitoes.

\section{Mosquito collection}

Mosquito collections were conducted during five rainy seasons. The larval sampling periods were June to August 2012 (termed June 2012), October to November 2012 (termed October 2012), May to July 2013 (termed June 2013), October to November 2013 (termed October 2013) and June to August 2014 (termed June 2014). In every survey, mosquito larvae were collected across the villages from several temporary breeding habitats, including household water storage [13]. Whenever possible, more than six larval habitats were examined per village. Mosquito larvae were transported to CREC, Cotonou and reared in an insectary under standard conditions (relative humidity $80 \% \pm 10 \%$ and temperature $25{ }^{\circ} \mathrm{C} \pm 2{ }^{\circ} \mathrm{C}$ ). Adult mosquitoes were maintained with $10 \%$ honey solution after emergence.

\section{Insecticide susceptibility test}

Bioassays were carried out on 2-5 old females using deltamethrin at the diagnostic dose of $0.05 \%$ according to standard WHO procedures [14]. The laboratory susceptible reference strain of An. gambiae (Kisumu) was used to

Table 1 Localisation and demographic information of study area

\begin{tabular}{llll}
\hline & Coordinates & Area $\left(\mathrm{km}^{2}\right)$ & Population \\
\hline Ifangni & $6^{\circ} 40^{\prime} \mathrm{N}, 2^{\circ} 43^{\prime} \mathrm{E}$ & 242 & 71,606 \\
Sakete & $6^{\circ} 44^{\prime} \mathrm{N}, 2^{\circ} 39^{\prime} \mathrm{E}$ & 432 & 70,604 \\
Pobe & $6^{\circ} 58^{\prime} \mathrm{N}, 2^{\circ} 39^{\prime} \mathrm{E}$ & 400 & 82,910 \\
Ketou & $7^{\circ} 21^{\prime} \mathrm{N}, 2^{\circ} 36^{\prime} \mathrm{E}$ & 2183 & 100,499 \\
\hline
\end{tabular}


check the quality of the impregnated paper. After $1 \mathrm{~h}$ of insecticide exposure, mosquitoes were transferred to holding tubes and fed with $10 \%$ honey solution. Mortality was recorded $24 \mathrm{~h}$ post-exposure. For each test, mosquitoes were also exposed to untreated paper to assess natural (control) mortality and to keep a batch of non-exposed mosquitoes for biochemical and molecular studies. Abbott's formula was used to correct the mortality when control mortality was between 5 and $20 \%$. After the test, legs were cut from control nonexposed mosquitoes for molecular determination and bodies were kept in RNA later at $-20{ }^{\circ} \mathrm{C}$ for mRNA expression. Another batch was frozen at $-80^{\circ} \mathrm{C}$ for biochemical studies.

\section{Molecular and biochemical assays}

Genomic DNA was extracted using cetyl trimethyl ammonium bromide (CTAB) $2 \%$ method modified from Doyle 1987 [15]. Briefly, mosquitoes were ground in CTAB $2 \%$ then heated in a water bath at $65^{\circ}$ for $5 \mathrm{~min}$. Chloroform was added to tubes, mixed by inversion, centrifuged and the upper phase transferred into another tube. DNA was precipitated with isopropanol and then washed once with $70 \%$ cold ethanol. DNA was dried and suspended in distilled water. Species determination was performed by PCR [16]. The 1014 F and $1014 S \mathrm{kdr}$ mutations were detected by allelic discrimination Taqman assays as described by Bass [17] on field nonexposed females. Biochemical assay was used to quantify amounts of mixed function of oxidases (MFO), glutathione S-transferases (GST) and activities of non-specific esterase (NSE) using 30 female mosquitoes (non-exposed) for each village as described by Hemingway [18]. Each plate contained 10 unfed Kisumu adults used as the susceptible control. These biochemical tests were carried out on mosquitoes collected in June 2012 and June 2013 only due to insufficient sample size from others surveys.

RNA extraction and reverse transcription quantitative PCR Pools of each Anopheles species were used to determine the relative gene expression of CYP6M2, CYP6P3 and GSTD3 by qPCR using SYBR Green. Total mRNA was extracted from batches of five mosquitoes (stored in RNA later) using Isolate RNA micro kit (Bioline) according to the manufacturer's instructions. Quantity and quality of mRNA were assessed using Nanodrop spectrophotometer (Nanodrop technologies). SuperScript III Reverse Transcriptase ${ }^{\mathrm{TM}}$ was used to synthesize first strand cDNA. The Kisumu was used as reference strain and the ribosomal gene RSP7 as housekeeping gene (shown to be consistent and with no differential expression between susceptible and resistant [19]). Three biological replicates were run for each sample and primers were designed on NCBI (http://www.ncbi.nlm.nih.gov/ tools/primer-blast/) (Table 2). Real time PCR was run on
Applied Bio systems ViiA7. Standard curves were generated using five times serially diluted cDNA sample to assess PCR efficiency. The PCR efficiency criterion was $100 \pm 10 \%$ for all of the genes and a single melting curve peak indicating specificity (Table 2). The cDNA was diluted 10-fold in this concentration that fitted within the dynamic range of each qPCR and stored at $-20^{\circ} \mathrm{C}$.

\section{Data analysis}

Mann-Whitney test implemented in R 2.15.2 software is used to compare (i) mosquito mortalities between villages and sampling periods; and (ii) levels of enzymatic activity between the lab reference strain and field mosquitoes. A linear mixed model with villages as random effect implemented in R 2.15.2 software was used to test the effect of surveys and villages on mortality. WHO criteria for discriminating individuals for susceptibility/resistance status were applied: 98-100 \% mortality indicating susceptibility; 90-97 \% suspected resistance and $<90 \%$ mortality-confirmed resistance [14]. Spearman's correlation test was used to investigate (i) the link between $k d r$ allele frequency of field mosquitoes and mortality; (ii) between Anopheles species and mortality; and (iii) the fold expression of cytochrome P450 and the mortality by survey. All differences were considered significant for $P$-value $<0.05$. The relative expression of target genes were determined according to $\Delta \Delta \mathrm{Ct}$ methods described by Schmittgen \& Livak [20]. QPCR data were analysed using simple statistical randomization tests implemented in REST 2009 software.

\section{Results}

\section{Vector composition}

Anopheles coluzzii and An. gambiae were found in sympatry in all villages. In June 2012, An. coluzzii was predominant in all sites (82\%) and An. gambiae and hybrids represented only 12 and $6 \%$ of the species collected, respectively. Proportions of hybrids decreased over time to reach $0.3 \%$ in June 2014. At the same time the proportion of An. coluzzii and An. gambiae fluctuated between 40 and $60 \%$ (Fig. 1).

\section{Resistance status}

Figure 2 shows the phenotypic resistance of malaria vectors to deltamethrin in thirteen villages during three years of follow-up. Mortality in controls never exceeded $5 \%$ indicating that no contamination occurred during bioassays, then Abbott's formula was not applied. Susceptibility tests were run on 3323; 1203; 827; 2955; and 1192 female Anopheles in June 2012, October 2012, June 2013, October 2013 and June 2014, respectively. There was no information available in three villages: Ketougbekon, Koaïdjedo (June 2013), Ko-aïdjedo, Kokoumolou (October 2013), Ketougbekon, Ko-aïdjedo, Kokoumolou (June 2014), 
Table 2 Primers used in RT-qPCR

\begin{tabular}{llll}
\hline Primer & Accession number & Primer sequence (5'-3') & PCR efficiency (\%) \\
\hline CYP6M2 & VectorBase: AGAP008212 & Fw: TCGGGATGTGTGCGTTCGGC & 100 \\
& & Rv: TCGTGTCTCGCACCGCGTTC & \\
GSTD3 & VectorBase: AGAP004382 & Fw: CTAAGCTTAATCCGCAACATACCA & 93 \\
RPS7 & VectorBase: AGAP010592 & Fw: ATTGCCGAGCGCCGCATTCT & 100 \\
& & Rv: GACGCGGATACGCTTGCCGA & 97 \\
CYP6P3 & VectorBase: AGAP002865 & Rv: ATATGATTGACGAAACCCTTCGGAAG \\
\hline
\end{tabular}

due to the absence of Anopheles mosquitoes in all breeding habitats during the visit. The linear mixed model (AIC = $96, \mathrm{BIC}=57$ ) showed that the sampling period had a significant effect on mortalities ("time-effect", $P<0.001$ ) but no effect of the villages $(P=0.9946)$ was recorded (Fig. 2$)$.

In June 2012 and June 2014 (beginning of the rainy season) all Anopheles populations from the 13 villages were resistant to deltamethrin (mortalities < $90 \%$ ). From October 2012 to October 2013, mortalities exceeded $90 \%$, indicating that most of the Anopheles populations collected in the villages were suspected to be resistant. Three villages showed mortalities up to $97 \%$ at the same period, indicating susceptibility. There was no strong correlation between mortality and proportions of both Anopheles species: An. gambiae ( $\left.\rho=0.34, \mathrm{CI}_{95 \%}=0.12-0.52, P=0.008\right)$, An. coluzzii $\left(\rho=-0.28, \mathrm{CI}_{95 \%}=-0.510--0.009, P=0.030\right)$.

\section{Kdr mutations}

In the study area, genotyping results showed that $1014 \mathrm{~F}$ $k d r$ allele frequency increased over time i.e. $f(1014 \mathrm{~F})$ was $0.67 ; 0.91 ; 0.92 ; 0.90$ and 0.92 in June 2012, October 2012, June 2013, October 2013 and June 2014, respectively (Table 4). $K d r$ mutation was almost fixed in the study area and equally distributed between $A n$. coluzzii and An. gambiae. Anopheles susceptibility to deltamethrin was not correlated with the $k d r$ frequency over time $\left(\rho=0.146, \mathrm{CI}_{95 \%}=0.151-0.444, P=0.336\right)$.

\section{Metabolic resistance}

Activities of esterases, glutathione S-transferases and mixed function of oxidases were measured using mosquitoes collected in June 2012 and June 2013. Results showed a higher GST activity in field Anopheles in June
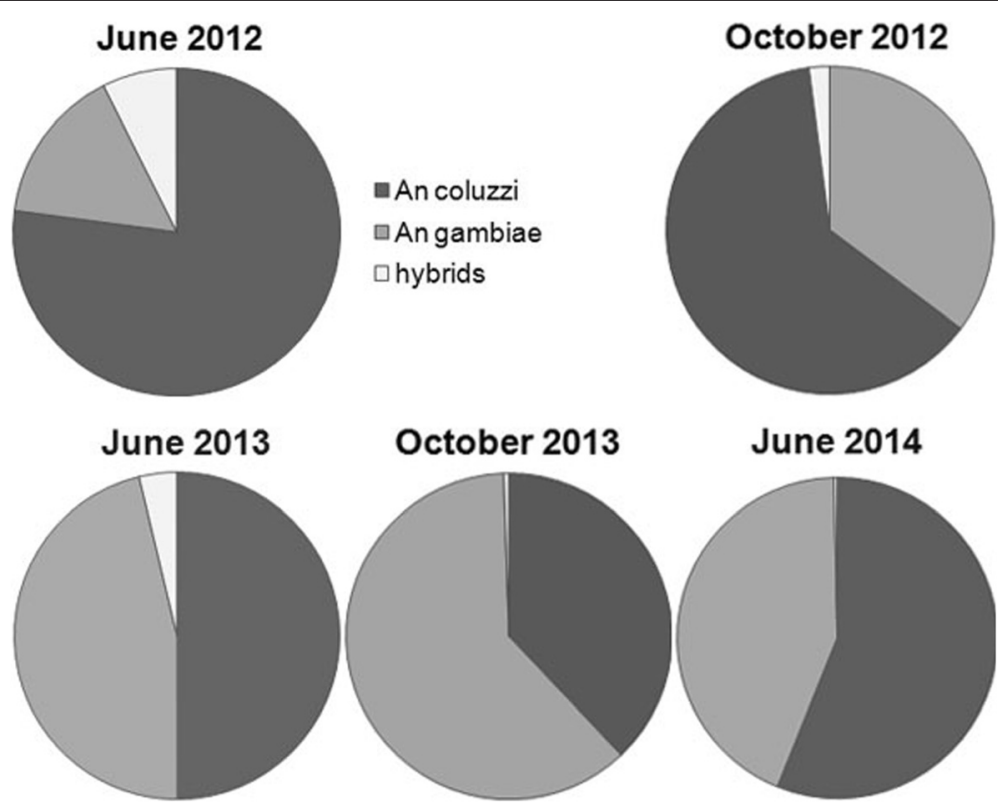

October 2013
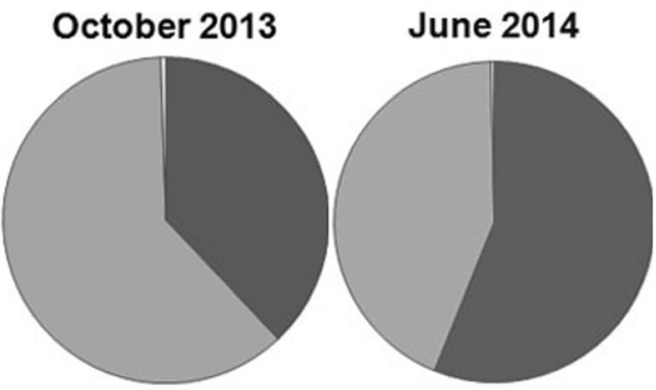

Fig. 1 Proportions of Anopheles gambiae (s.l.) major species over sampling periods 


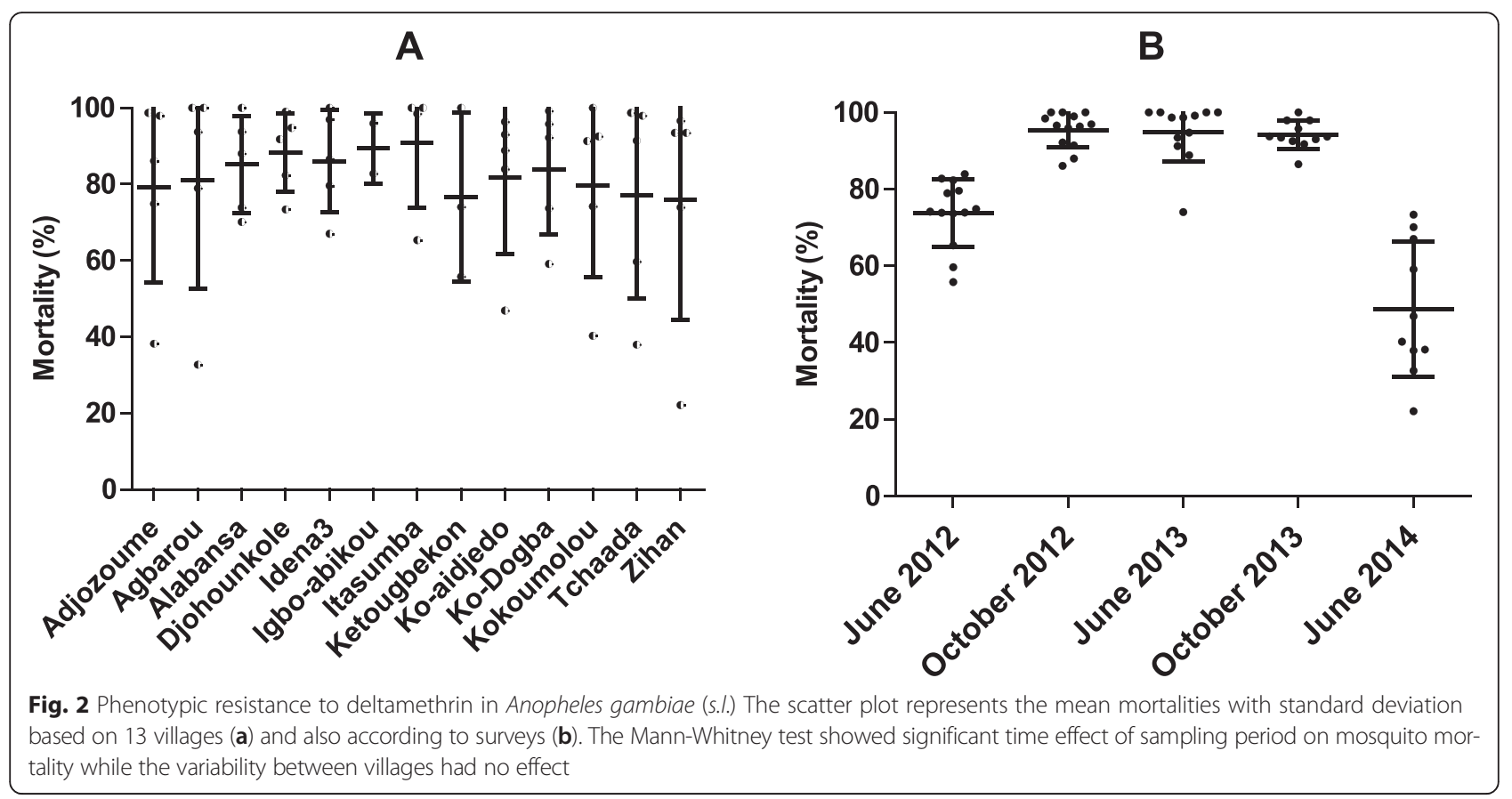

2012 and 2013 compared to the susceptible reference strain (Table 3). Similarly, the level of $\alpha$-esterase activity of field mosquitoes was significantly higher than that at Kisumu in June 2012. Conversely, we did not report higher activity of $\mathrm{P} 450$ in field populations at the two surveys compared to the susceptible reference strain $(P>0.05)$.

The expression of detoxification genes was also measured by RT-qPCR in both species (Fig. 3). Only An. gambiae showed upregulation of metabolic genes compared to reference strain. GSTD3 was upregulated in June 2012 and June 2014, the mean fold changes (FC) were 1.8 and 49.3, respectively $(P<0.001)$ (Fig. 3). CYP6P3 and CYP6M2 were upregulated in June 2014 during the beginning of the rainy season; the FC were 4.8 and 44.42 , respectively $(P<0.001)$. These genes were mostly down regulated in October 2012 and October 2013, suggesting a relationship between the level of expression of some P450 markers and the resistance phenotype to deltamethrin.

\section{Discussion}

This study addressed the dynamic of deltamethrin resistance in malaria vectors in the department of Plateau Benin, following a large scale implementation of malaria vector control tools. A combination of biological, biochemical and molecular assays were used to assess the frequency and mechanisms of pyrethroid-resistance in An. gambiae (s.l.) collected in 13 villages over three years. The results showed that An. coluzzii and An. gambiae were found in sympatry during all of the sampling periods but at various frequencies. A previous study demonstrated similar distribution of sibling species within An. gambiae (s.l.) complex in the study area [21].

Bioassay results showed significant variations of deltamethrin phenotypic resistance according to the surveys. Anopheles populations from the 13 villages were resistant to deltamethrin in June 2012 and June 2014 (< $90 \%$ mortality) but mostly susceptible in October 2012 and 2013 (only 5 of 13 populations showed mortality < $90 \%$ ). This strong variation of phenotypic resistance in such a short period of time is difficult to explain knowing that environmental conditions did not change much between surveys (temperature $25 \pm 2{ }^{\circ} \mathrm{C}$ and humidity $80 \pm 10 \%$ ). The frequency of the 1014 F kdr mutation was high in June 2012 in both species and did not increase much until June 2014. Consequently, it is unlikely that the $k d r$ mutation alone

Table 3 Detoxification enzyme activities of Anopheles in June 2012 and June 2013

\begin{tabular}{|c|c|c|c|c|c|c|c|c|}
\hline & \multicolumn{4}{|l|}{ June 2012} & \multicolumn{4}{|l|}{ June 2013} \\
\hline & Mean Anopheles & Mean reference & $\mathrm{FC}$ & $P$-value & Mean Anopheles & Mean reference & FC & $P$-value \\
\hline a-Naphthyl acetate & $0.202 \pm 0.08$ & $0.118 \pm 0.03$ & 1.71 & 0.0001 & $0.140 \pm 0.06$ & $0.147 \pm 0.08$ & 0.95 & 0.463 \\
\hline$\beta$-Naphthyl acetate & $0.141 \pm 0.07$ & $0.101 \pm 0.04$ & 1.39 & 0.0811 & $0.105 \pm 0.10$ & $0.117 \pm 0.09$ & 0.89 & 0.041 \\
\hline Oxydase (P450) & $0.094 \pm 0.05$ & $0.090 \pm 0.06$ & 1.04 & 0.7617 & $0.038 \pm 0.02$ & $0.091 \pm 0.03$ & 0.41 & 0.0166 \\
\hline GST & $0.264 \pm 0.15$ & $0.142 \pm 0.03$ & 1.86 & $<0.0001$ & $0.521 \pm 0.63$ & $0.280 \pm 0.65$ & 1.86 & 0.001 \\
\hline
\end{tabular}

Enzyme activities are expressed by $\mathrm{mg}$ of total proteins. Fold Change (FC) is the ratio of mean activity in Anopheles/mean activity in reference strain 


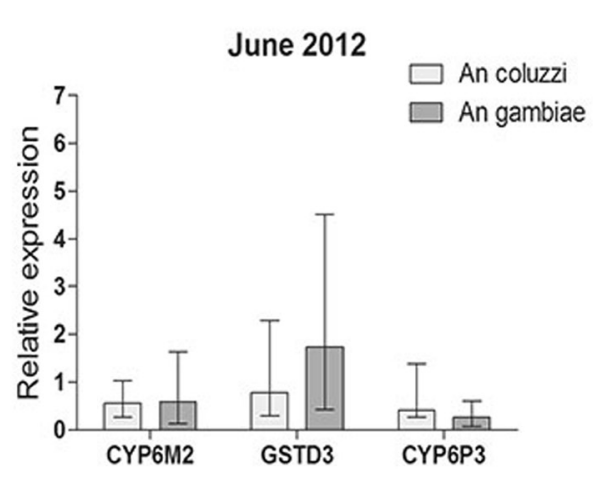

October 2012

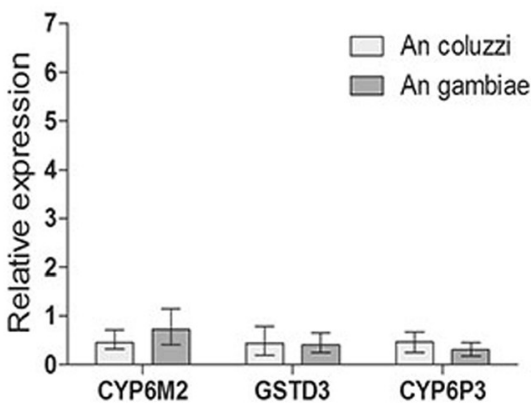

June 2013

October 2013
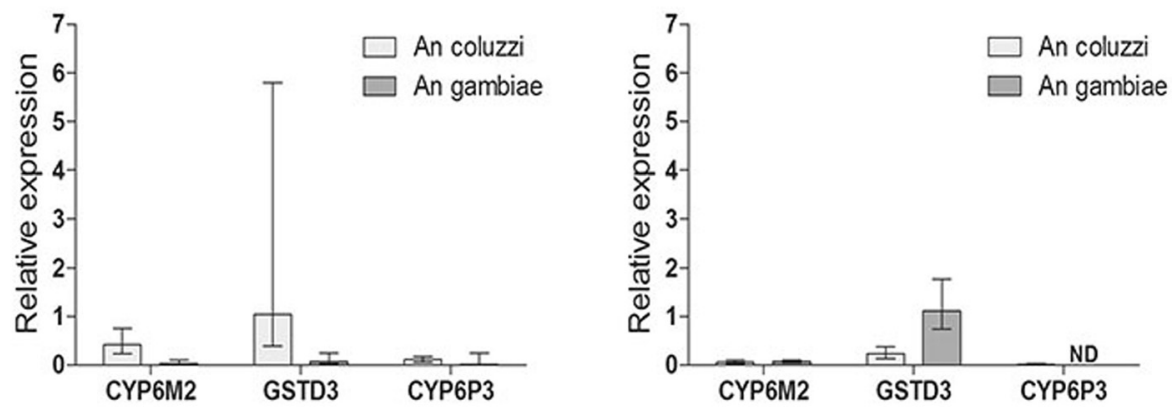

June 2014

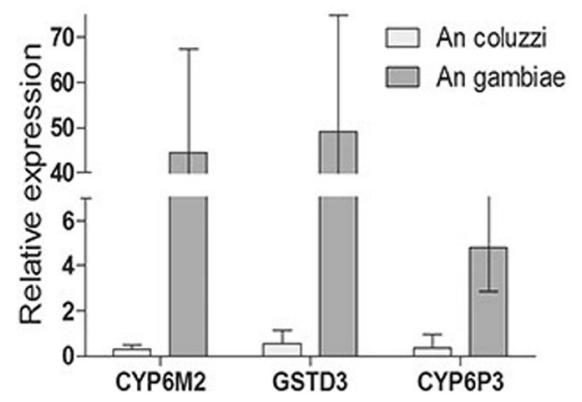

Fig. 3 Relative expression of detoxification genes. $\Delta \Delta \mathrm{Ct}$ method was used for analysis. Bar charts represent the mean expression of three enzymes of field Anopheles. Error bars represent $95 \%$ confidence interval. ND, no data

contributed greatly to the phenotype observed. A previous study questioned the causal association between $k d r$ genotype and pyrethroid resistance (especially for type II pyrethroids) and suggested that the $k d r$ genotype may not necessarily be the best predictor of resistance in malaria vectors. The $1014 \mathrm{~S} k d r$ mutation originally from East Africa [22] was not detected in the present study. So far this mutation was found in Benin at a very low frequency in An. arabiensis [8].

In contrast, a significant increase in metabolic gene expression was reported in An. gambiae (s.s.) over the threeyear follow-up. Overexpression of three metabolic genes, CYP6M2 (> 40-fold), GSTD3 (> 40-fold) and CYP6P3 (> 4fold), were reported in June 2014, hence indicating a recent and strong selection pressure on this mosquito species.
Interestingly, the high gene expression was associated with low mortality rates as measured by WHO bioassays. This finding supports the involvement of these metabolic markers in deltamethrin-resistant phenotype. Downregulation of these genes in June 2012 despite the presence of resistance phenotype may be explained by the low number of An. gambiae collected in that survey (Table 4) and/or by the involvement of other (non-detectable) metabolic detoxification genes. The differential expression of metabolic markers between An. gambiae and An. coluzzi has been reported in Benin [23] and may reflect differential exposure to insecticides/xenobiotics at larval and/or adult stage.

CYP6M2 and CYP6P3 are regularly associated with pyrethroid resistance [24] and have been validated as 
Table $4 \mathrm{Kdr}$ allelic frequencies in An. coluzzi and An. gambiae. f(1014)F was determined by qPCR. N represents the number of alleles tested

\begin{tabular}{|c|c|c|c|c|c|c|c|c|c|c|c|c|c|c|c|c|c|c|c|c|}
\hline \multirow[t]{3}{*}{ Villages } & \multicolumn{4}{|l|}{ June 2012} & \multicolumn{4}{|c|}{ October 2012} & \multicolumn{4}{|l|}{ June 2013} & \multicolumn{4}{|c|}{ October 2013} & \multicolumn{4}{|l|}{ June 2014} \\
\hline & \multicolumn{2}{|l|}{ An. coluzzi } & \multicolumn{2}{|c|}{ An. gambiae } & \multicolumn{2}{|l|}{ An. coluzzi } & \multicolumn{2}{|c|}{ An. gambiae } & \multicolumn{2}{|l|}{ An. coluzzi } & \multicolumn{2}{|l|}{ An. gambiae } & \multicolumn{2}{|l|}{ An. coluzzi } & \multicolumn{2}{|c|}{ An. gambiae } & \multicolumn{2}{|l|}{ An. coluzzi } & \multicolumn{2}{|c|}{ An. gambiae } \\
\hline & $f(1014) F$ & N & $f(1014) F$ & $\mathrm{~N}$ & $f(1014) F$ & $\mathrm{~N}$ & $f(1014) F$ & N & $f(1014) F$ & N & $f(1014) F$ & N & $f(1014) F$ & N & $f(1014) F$ & $\mathrm{~N}$ & $f(1014) F$ & $\mathrm{~N}$ & $f(1014) F$ & $\mathrm{~N}$ \\
\hline Adjozoume & $\begin{array}{l}0.65 \\
(0.51-0.76)\end{array}$ & 62 & $\begin{array}{l}0.7 \\
(0.34-0.93)\end{array}$ & 10 & $\begin{array}{l}1 \\
(0.39-1)\end{array}$ & 4 & $\begin{array}{l}1 \\
(0.90-1)\end{array}$ & 38 & $\begin{array}{l}1 \\
(0.83-1)\end{array}$ & 20 & $\begin{array}{l}1 \\
(0.95-1)\end{array}$ & 72 & - & - & $\begin{array}{l}1 \\
(0.92-1)\end{array}$ & 48 & - & - & $\begin{array}{l}1 \\
(0.92-1)\end{array}$ & 50 \\
\hline Agbarou & $\begin{array}{l}0.73 \\
(0.56-0.85)\end{array}$ & 40 & $\begin{array}{l}0.75 \\
(0.42-0.94)\end{array}$ & 12 & $\begin{array}{l}1 \\
(0.39-1)\end{array}$ & 4 & $\begin{array}{l}1 \\
(0.91-1)\end{array}$ & 42 & $\begin{array}{l}0.8 \\
(0.61-0.92)\end{array}$ & 30 & $\begin{array}{l}1 \\
(0.83-1)\end{array}$ & 20 & $\begin{array}{l}0.83 \\
(0.71-0.90)\end{array}$ & 70 & $\begin{array}{l}0.99 \\
(0.93-0.99)\end{array}$ & 82 & $\begin{array}{l}0.88 \\
(0.78-0.93)\end{array}$ & 82 & $\begin{array}{l}1 \\
(0.91-1)\end{array}$ & 40 \\
\hline Alabansa & $\begin{array}{l}0.73 \\
(0.59-0.83)\end{array}$ & 62 & $\begin{array}{l}0.68 \\
(0.47-0.84)\end{array}$ & 28 & $\begin{array}{l}0.82 \\
(0.65-0.93)\end{array}$ & 34 & $\begin{array}{l}1 \\
(0.94-1)\end{array}$ & 68 & $\begin{array}{l}0.89 \\
(0.75-0.97)\end{array}$ & 38 & $\begin{array}{l}0.97 \\
(0.89-0,99)\end{array}$ & 66 & $\begin{array}{l}0.92 \\
(0.77-0.98)\end{array}$ & 36 & $\begin{array}{l}0.99 \\
(0.96-0.99)\end{array}$ & 170 & $\begin{array}{l}0.89 \\
(0.76-0.96)\end{array}$ & 46 & $\begin{array}{l}1 \\
(0.93-1)\end{array}$ & 54 \\
\hline Djohounkole & $\begin{array}{l}0.68 \\
(0.58-0.77)\end{array}$ & 92 & $\begin{array}{l}1 \\
(0.54-1)\end{array}$ & 6 & $\begin{array}{l}0.89 \\
(0.65-0.98)\end{array}$ & 18 & $\begin{array}{l}0.90 \\
(0.68-0,98)\end{array}$ & 20 & $\begin{array}{l}0.84 \\
(0.71-0.92)\end{array}$ & 56 & $\begin{array}{l}0.91 \\
(0.74-0.98)\end{array}$ & 32 & $\begin{array}{l}0.94 \\
(0.84-0.98)\end{array}$ & 62 & $\begin{array}{l}1 \\
(0.95-1)\end{array}$ & 88 & $\begin{array}{l}0.83 \\
(0.70-0.91)\end{array}$ & 58 & $\begin{array}{l}1 \\
(0.73-1)\end{array}$ & 12 \\
\hline Idena3 & $\begin{array}{l}0.68 \\
(0.58-0.76)\end{array}$ & 118 & $\begin{array}{l}0.75 \\
(0.34-0,96)\end{array}$ & 8 & $\begin{array}{l}0.88 \\
(0.47-0,99)\end{array}$ & 8 & $\begin{array}{l}0.99 \\
(0.94-0,99)\end{array}$ & 106 & $\begin{array}{l}0.93 \\
(0.66-0.99)\end{array}$ & 14 & $\begin{array}{l}1 \\
(0.87-1)\end{array}$ & 28 & $\begin{array}{l}0.71 \\
(0.41-0.91)\end{array}$ & 14 & $\begin{array}{l}1 \\
(0.97-1)\end{array}$ & 182 & $\begin{array}{l}0.87 \\
(0.75-0.94)\end{array}$ & 54 & $\begin{array}{l}0.97 \\
(0.88-0.99)\end{array}$ & 46 \\
\hline Igbo-abikou & $\begin{array}{l}0.73 \\
(0.54-0.87)\end{array}$ & 30 & $\begin{array}{l}0.83 \\
(0.35-0,99)\end{array}$ & 6 & $\begin{array}{l}0.85 \\
(0.65-0.95)\end{array}$ & 26 & $\begin{array}{l}0.98 \\
(0.93-0.99)\end{array}$ & 104 & $\begin{array}{l}0.75 \\
(0.34-0.96)\end{array}$ & 8 & $\begin{array}{l}1 \\
(0.95-1)\end{array}$ & 90 & $\begin{array}{l}1 \\
(0.76-1)\end{array}$ & 14 & $\begin{array}{l}1 \\
(0.97-1)\end{array}$ & 130 & $\begin{array}{l}0.78 \\
(0.65-0.87)\end{array}$ & 60 & $\begin{array}{l}1 \\
(0.91-1)\end{array}$ & 42 \\
\hline Itasumba & $\begin{array}{l}0.66 \\
(0.50-0.79)\end{array}$ & 44 & $\begin{array}{l}0.5 \\
(0.19-0.98)\end{array}$ & 2 & $\begin{array}{l}0.78 \\
(0.69-0.86)\end{array}$ & 96 & $\begin{array}{l}1 \\
(0.63-1)\end{array}$ & 8 & $\begin{array}{l}0.79 \\
(0.69-0.86)\end{array}$ & 100 & $\begin{array}{l}1 \\
(0.15-1)\end{array}$ & 2 & $\begin{array}{l}0.82 \\
(0.75-0.86)\end{array}$ & 202 & - & - & $\begin{array}{l}0.71 \\
(0.60-0.80)\end{array}$ & 80 & - & - \\
\hline Ketougbekon & $\begin{array}{l}0.65 \\
(0.50-0.78)\end{array}$ & 52 & $\begin{array}{l}0.83 \\
(0.35-0.99)\end{array}$ & 6 & $\begin{array}{l}0.84 \\
(0.71-0.92)\end{array}$ & 56 & $\begin{array}{l}0.96 \\
(0.87-0.99)\end{array}$ & 68 & $\begin{array}{l}0,88 \\
(0.71-0.96)\end{array}$ & 32 & $\begin{array}{l}1 \\
(0.81-1)\end{array}$ & 18,00 & $\begin{array}{l}0.91 \\
(0.84-0.95)\end{array}$ & 122 & $\begin{array}{l}0.84 \\
(0.73-0.91)\end{array}$ & 74 & $\begin{array}{l}0.90 \\
(0.80-0.96)\end{array}$ & 72 & $\begin{array}{l}0.86 \\
(0.67-0.95)\end{array}$ & 28 \\
\hline Ko-aidjedo & $\begin{array}{l}0.62 \\
(0.40-0.79)\end{array}$ & 26 & $\begin{array}{l}0.42 \\
(0.15-0.72)\end{array}$ & 12 & $\begin{array}{l}0.5 \\
(0.19-1)\end{array}$ & 2 & $\begin{array}{l}0.96 \\
(0.89-0.99)\end{array}$ & 84 & - & - & - & - & - & - & - & - & - & - & - & - \\
\hline Ko-Dogba & $\begin{array}{l}0.64 \\
(0.52-0.75)\end{array}$ & 76 & $\begin{array}{l}0.73 \\
(0.56-0.85)\end{array}$ & 40 & $\begin{array}{l}1 \\
(0.39-1)\end{array}$ & 4 & $\begin{array}{l}0.92 \\
(0.83-0.96)\end{array}$ & 84 & $\begin{array}{l}0.83 \\
(0.51-0.97)\end{array}$ & 12 & $\begin{array}{l}1 \\
(0.84-1)\end{array}$ & 22 & $\begin{array}{l}0.5 \\
(0.06-0.93)\end{array}$ & 4 & $\begin{array}{l}0.97 \\
(0.90-0.99)\end{array}$ & 90 & - & - & - & - \\
\hline Kokoumolou & $\begin{array}{l}0.60 \\
(0.46-0.71)\end{array}$ & 62 & $\begin{array}{l}0.79 \\
(0.49-0.95)\end{array}$ & 14 & $\begin{array}{l}0.87 \\
(0.79-0,92)\end{array}$ & 108 & $\begin{array}{l}1 \\
(0.86-1)\end{array}$ & 26 & $\begin{array}{l}0.9 \\
(0.68-0.98)\end{array}$ & 20 & $\begin{array}{l}1 \\
(0.81-1)\end{array}$ & 18 & - & - & - & - & - & - & - & - \\
\hline Tchaada & $\begin{array}{l}0.84 \\
(0.74-0.90)\end{array}$ & 98 & - & - & $\begin{array}{l}0.94 \\
(0.80-0.99)\end{array}$ & 34 & $\begin{array}{l}0.92 \\
(0.77-0.98)\end{array}$ & 36 & $\begin{array}{l}0.86 \\
(0.71-0.94)\end{array}$ & 42 & $\begin{array}{l}0.88 \\
(0.47-0.99)\end{array}$ & 8 & $\begin{array}{l}0.92 \\
(0.84-0.96)\end{array}$ & 92 & $\begin{array}{l}0.98 \\
(0.87-0.99)\end{array}$ & 68 & $\begin{array}{l}0.93 \\
(0.79-0.98)\end{array}$ & 40 & $\begin{array}{l}1 \\
(0.63-1)\end{array}$ & 8 \\
\hline Zihan & $\begin{array}{l}0.36 \\
(0.23-0.49)\end{array}$ & 58 & $\begin{array}{l}0.63 \\
(0.24-0.91)\end{array}$ & 8 & $\begin{array}{l}0.89 \\
(0.80-0.94)\end{array}$ & 82 & $\begin{array}{l}0.93 \\
(0.79-0.98)\end{array}$ & 40 & $\begin{array}{l}0.84 \\
(0.72-0.91)\end{array}$ & 68 & $\begin{array}{l}1 \\
(0.83-1)\end{array}$ & 20 & $\begin{array}{l}0.78 \\
(0.67-0.86)\end{array}$ & 78 & $\begin{array}{l}1 \\
(0.94-1)\end{array}$ & 68 & $\begin{array}{l}1 \\
(0.69-1)\end{array}$ & 10 & $\begin{array}{l}1 \\
(0.91-1)\end{array}$ & 40 \\
\hline
\end{tabular}


pyrethroid metabolizers $[25,26]$. No correlation was noted, however, between the oxidase activity and P450 gene expression. This can be explained by a lack of sensitivity and specificity of biochemical assays that employ generic heme peroxidase assays that are recognized by many members of the enzyme family [25]. The use of mixed populations ( $A n$. gambiae and An. coluzzii) during biochemical tests may have also affected the outcomes. Overexpression of CYP6M2 and CYP6P3 is widespread in West Africa including Benin, Nigeria [19], Ghana [26] and should be routinely monitored by national malaria control programmes. In addition, GSTD3 was found up regulated in Anopheles in June 2012 and 2014 hence correlating results of both, the biochemical test and bioassays. GSTD3 was found upregulated in DDT-resistant An. arabiensis and $A n$. gambiae in Burkina Faso and Benin, respectively [8]. GSTs are regularly found overexpressed in many pyrethroid-resistant mosquitoes [27, 28]. Some studies suggested their potential role against oxidative stress [29] and in pyrethroid sequestration [30]. Although the role of mosquito GSTs in pyrethroid resistance is likely, understanding the underlying mechanisms requires further investigations.

In Benin, the use of pesticides for both vector control and agricultural practices (cotton crops and vegetable farms) are known to be a major source of selection pressure on malaria vectors [31-33]. For example, a randomized controlled trial conducted in southern Benin showed an increase in the $k d r$ frequency from 20 to $80 \%$ in An. gambiae eighteen months after the distribution of LLIN at community level [33]. We suspect that the increased coverage of deltamethrin-LLINs in 2014 in the study area ( $80 \%, \mathrm{NMCP})$ has contributed to selection for pyrethroid-resistance metabolic markers. The role of agricultural practices in the selection of insecticide resistance in An. gambiae remains unknown. No significant changes in land use and agricultural practices were observed during the three-year follow-up but we could not record the type and amount of insecticides used by native farmers for crop protection. Similarly, the larval exposure to various xenobiotics (e.g. heavy metals, oils, fungicides, pollutants) that are known to modulate/enhance the metabolic detoxification profile of mosquitoes could not be investigated $[34,35]$. Clearly, much work has to be done to address the environmental factors contributing to resistance selection in malaria vectors in Benin.

The present study was part of a multidisciplinary project funded by the Bill \& Melinda Gates Foundation that aims at addressing whether insecticide resistance can impact on the effectiveness of malaria vector control tools in Africa. Up to now the results of the first year follow-up did show substantial impact of insecticide resistance on the efficacy of LLINs in southern Benin [36] but analyses of years 2 and 3 are still ongoing.

\section{Conclusions}

This study monitored the levels and mechanisms of deltamethrin resistance in major malaria vectors in the Plateau department, Benin, after a three-year implementation of malaria vector control. The results showed that resistance to deltamethrin in malaria vectors was widespread and multifactorial. We also suspect that the increase in deltamethrin resistance between 2012 and 2014 resulted from an increased expression of metabolic detoxification genes (CYP6M2 and CYP6P3) rather than $k d r$ mutations. It is now urgent to evaluate further the impact of metabolic resistance on the efficacy of vector control interventions using pyrethroid insecticides.

\section{Abbreviations}

CTAB, Cetyl Trimethyl Ammonium Bromide; DDT, Dichlorodiphényltrichloroéthane; GST, Gluthatione S-transferase; IRS, Indoor Residual Spraying; Kdr, Knockdown resistance; LLIN, Long Lasting Insecticide Nets; MFO, Mixed Function of Oxidase; NMCP, National Malaria Control Program; NSE, Non-Specific Esterase; WHO, World Health Organization

\section{Acknowledgements}

The authors thank Martin Donnelly for proofreading the manuscript and the Mediterranean Infection foundation for supporting GAY.

\section{Funding}

Field samplings were supported by the Bill and Melinda Gates Foundation (Grant Number 48499.01). This research forms part of a multi-country study coordinated by the Global Malaria Program of the World Health Organization.

\section{Availability of data and material}

Not applicable.

\section{Authors' contributions}

GAY, participated to field studies, data analysis and manuscript writing. SA, JA performed molecular biology. CS, ID, participated to field collection and bioassays. MA, VC, SC, participated in the coordination and study design and manuscript preparation. All authors read and approved the final version of the manuscript.

\section{Competing interests}

The authors declare that they have no competing interests.

\section{Consent for publication}

Not applicable.

Ethics approval and consent to participate

Not applicable.

\section{Author details}

${ }^{1}$ Institut de Recherche pour le Développement (IRD), Maladies Infectieuses et Vecteurs: Ecologie, Génétique, Evolution et Contrôle (MIVEGEC), UMR UM1-UM2 - CNRS 5290 - IRD 224, Montpellier, France. ${ }^{2}$ Centre de Recherche Entomologique de Cotonou (CREC), Cotonou, Bénin. ${ }^{3}$ Department of Entomology, Faculty of Agriculture, Kasetsart University, 50 Ngam Wong Wan Rd, Lat Yao Chatuchak, Bangkok 10900, Thailand.

Received: 20 February 2016 Accepted: 22 June 2016

Published online: 04 July 2016

References

1. World Health Organisation HEADQUARTERS. The technical basis for coordinated action against insecticide resistance. 2011 [cited 2016 Jun 23]; Available from: http://citeseerx.ist.psu.edu/viewdoc/download?doi=10.1.1. 417.9563\&rep=rep $1 \&$ type $=$ pdf

2. Corbel V, NGuess R. Distribution, Mechanisms, impact and management of insecticide resistance in malaria vectors: A pragmatic review. In: Manquin S, editor. Anopheles Mosquitoes - New Insights Malar. Vectors [Internet]. 
InTech; 2013 [cited 2016 May 19]. Available from: http://www.intechopen. com/books/anopheles-mosquitoes-new-insights-into-malaria-vectors/ distribution-mechanisms-impact-and-management-of-insecticide-resistancein-malaria-vectors-a-pragmat

3. Martinez-Torres $D$, Chandre F, Williamson MS, Darriet F, Bergé JB, Devonshire AL, et al. Molecular characterization of pyrethroid knockdown resistance $(\mathrm{kdr})$ in the major malaria vector Anopheles gambiae s.s. Insect Mol Biol. 1998;7:179-84.

4. Jones CM, Liyanapathirana M, Agossa FR, Weetman D, Ranson H, Donnelly MJ, et al. Footprints of positive selection associated with a mutation (N1575Y) in the voltage-gated sodium channel of Anopheles gambiae. Proc Natl Acad Sci. 2012;109:6614-9.

5. Hemingway J, Ranson H. Insecticide resistance in insect vectors of human disease. Annu Rev Entomol. 2000;45:371-91.

6. Awolola TS, Oduola OA, Strode C, Koekemoer LL, Brooke B, Ranson H. Evidence of multiple pyrethroid resistance mechanisms in the malaria vector Anopheles gambiae sensu stricto from Nigeria. Trans R Soc Trop Med Hyg. 2009;103:1139-45.

7. Ranson H, N'guessan R, Lines J, Moiroux N, Nkuni Z, Corbel V. Pyrethroid resistance in African anopheline mosquitoes: what are the implications for malaria control? Trends Parasitol. 2011;27:91-8.

8. Djègbè I, Boussari O, Sidick A, Martin T, Ranson H, Chandre F, et al. Dynamics of insecticide resistance in malaria vectors in Benin: first evidence of the presence of L1014S kdr mutation in Anopheles gambiae from West Africa. Malar J. 2011:10:261.

9. Asidi A, N'Guessan R, Akogbeto M, Curtis C, Rowland M. Loss of household protection from use of insecticide-treated nets against pyrethroid-resistant mosquitoes, Benin. Emerg Infect Dis. 2012;18:1101-6.

10. Djègbè I, Agossa FR, Jones CM, Poupardin R, Cornelie S, Akogbéto M, et al. Molecular characterization of DDT resistance in Anopheles gambiae from Benin. Parasit Vectors. 2014;7:409.

11. WHO | World Malaria Report 2013 [Internet]. WHO. [cited 2016 Jan 21] Available from: http://www.who.int/malaria/publications/world_malaria_ report_2013/en/

12. Nwane P, Etang J, Chouaibou M, Toto CJ, Kerah-Hinzoumbé C, Mimpfoundi R, et al. Trends in DDT and pyrethroid resistance in Anopheles gambiae s.s. populations from urban and agro-industrial settings in southern Cameroon. BMC Infect Dis. 2009:9:163.

13. O'Malley C. Seven ways to a successful dipping career. Wing Beats. 1995;6:23-4.

14. WHO. Test procedures: for insecticide resistance monitoring in malaria vector mosquitoes. Geneva: World Health Organization; 2013.

15. Doyle J. A rapid DNA isolation procedure for small quantities of fresh leaf tissue. Phytochem Bull. 1987;19:11-15.

16. Santolamazza F, Calzetta M, Etang J, Barrese E, Dia I, Caccone A, et al. Distribution of knock-down resistance mutations in Anopheles gambiae molecular forms in west and west-central Africa. Malar J. 2008;7:74.

17. Bass C, Nikou D, Donnelly MJ, Williamson MS, Ranson H, Ball A, et al. Detection of knockdown resistance (kdr) mutations in Anopheles gambiae: a comparison of two new high-throughput assays with existing methods. Malar J. 2007:6:111

18. Hemingway J, Hawkes N, Prapanthadara L, Jayawardenal KG, Ranson H. The role of gene splicing, gene amplification and regulation in mosquito insecticide resistance. Philos Trans R Soc B Biol Sci. 1998;353:1695-9.

19. Djouaka R, Bakare A, Coulibaly O, Akogbeto M, Ranson H, Hemingway J, et al. Expression of the cytochrome P450s, CYP6P3 and CYP6M2 are significantly elevated in multiple pyrethroid resistant populations of Anopheles gambiae s.s. from Southern Benin and Nigeria. BMC Genomics. 2008;9:538.

20. Schmittgen TD, Livak KJ. Analyzing real-time PCR data by the comparative CT method. Nat Protoc. 2008:3:1101-8.

21. Sovi A, Djègbè I, Soumanou L, Tokponnon F, Gnanguenon V, Azondékon R, et al. Microdistribution of the resistance of malaria vectors to deltamethrin in the region of Plateau (southeastern Benin) in preparation for an assessment of the impact of resistance on the effectiveness of Long Lasting Insecticidal Nets (LLINs). BMC Infect Dis. 2014;14:103.

22. Ranson $H$, Jensen $B$, Vulule J, Wang $X$. Identification of a point mutation in the voltage-gated sodium channel gene of Kenyan Anopheles gambiae associated with resistance to DDT and pyrethroids. Insect Mol Biol. 2000;9:491.

23. Djègbè I, Agossa F, Jones $C$, Poupardin R. Molecular characterization of DDT resistance in Anopheles gambiae from Benin. Parasit Vectors. 2014;7:409.
24. Abdalla H, Wilding CS, Nardini L, Pignatelli P, Koekemoer LL, Ranson H, et al. Insecticide resistance in Anopheles arabiensis in Sudan: temporal trends and underlying mechanisms. Parasit Vectors. 2014;7:213.

25. Harris AF, Rajatileka S, Ranson H. Pyrethroid resistance in Aedes aegypti from Grand Cayman. Am J Trop Med Hyg. 2010;83:277-84.

26. Müller P, Chouaïbou M, Pignatelli P, Etang J, Walker ED, Donnelly MJ, et al. Pyrethroid tolerance is associated with elevated expression of antioxidants and agricultural practice in Anopheles arabiensis sampled from an area of cotton fields in Northern Cameroon. Mol Ecol. 2008;17:1145-55.

27. David J-P, Strode C, Vontas J, Nikou D, Vaughan A, Pignatelli PM, et al. The Anopheles gambiae detoxification chip: A highly specific microarray to study metabolic-based insecticide resistance in malaria vectors. Proc Natl Acad Sci U S A. 2005;102:4080-4.

28. Marcombe S, Mathieu RB, Pocquet N, Riaz M-A, Poupardin R, Sélior S, et al. Insecticide resistance in the dengue vector Aedes aegypti from Martinique: Distribution, mechanisms and relations with environmental factors. PLoS One. 2012;7:e30989.

29. Vontas JG, Small GJ, Hemingway J. Glutathione S-transferases as antioxidant defence agents confer pyrethroid resistance in Nilaparvata lugens. Biochem J. 2001;357:65-72

30. Kostaropoulos I, Papadopoulos Al, Metaxakis A, Boukouvala E, PapadopoulouMourkidou E. Glutathione S-transferase in the defence against pyrethroids in insects. Insect Biochem Mol Biol. 2001;31:313-9.

31. Akogbeto M, Yakoubou S. Resistance of malaria vectors to pyrethroids used for impregnated bednets, Benin, West Africa. Bull Soc Pathol Exot. 1999;92: 123-30.

32. Yadouléton A, Badirou K, Agbanrin R, Jöst $H$, Attolou R, Srinivasan R, et al. Insecticide resistance status in Culex quinquefasciatus in Benin. Parasit Vectors. 2015;8:17.

33. Corbel V, Akogbeto M, Damien GB, Djenontin A, Chandre F, Rogier C, et al. Combination of malaria vector control interventions in pyrethroid resistance area in Benin: a cluster randomised controlled trial. Lancet Infect Dis. 2012; 12:617-26.

34. Nkya TE, Akhouayri I, Poupardin R, Batengana B, Mosha F, Magesa S, et al. Insecticide resistance mechanisms associated with different environments in the malaria vector Anopheles gambiae: a case study in Tanzania. Malar J. 2014;13:28.

35. Poupardin R, Riaz MA, Vontas J, David JP, Reynaud S. Transcription profiling of eleven cytochrome P450s potentially involved in xenobiotic metabolism in the mosquito Aedes aegypti. Insect Mol Biol. 2010;19:185-93.

36. Tokponnon FT, Ogouyémi AH, Sissinto Y, Sovi A, Gnanguenon V, Cornélie S, et al. Impact of long-lasting, insecticidal nets on anaemia and prevalence of Plasmodium falciparum among children under five years in areas with highly resistant malaria vectors. Malar J. 2014;13:76.

\section{Submit your next manuscript to BioMed Central and we will help you at every step:}

- We accept pre-submission inquiries

- Our selector tool helps you to find the most relevant journal

- We provide round the clock customer support

- Convenient online submission

- Thorough peer review

- Inclusion in PubMed and all major indexing services

- Maximum visibility for your research

Submit your manuscript at www.biomedcentral.com/submit
Biomed Central 